\title{
EXPERIMENTAL STUDY OF RAILWAY \\ TRACKBED PRESSURE DISTRIBUTION UNDER DYNAMIC LOADING
}

\section{MYKOLA SYSYN ${ }^{*}$, VITALII KOVALCHUK ${ }^{2}$, OLGA NABOCHENKO ${ }^{3}$, YURI KOVALCHUK ${ }^{4}$, OLEG VOZNYAK ${ }^{5}$ \\ ${ }^{1}$ Institute of Railway Systems and Public Transport, Technical University of Dresden, Dresden, Germany ${ }^{2,3,5}$ Dept of the Rolling Stock and Track, Lviv Branch of Dnipro National University of Railway Transport, Lviv, Ukraine \\ ${ }^{4}$ Dept of Construction Industry, Lviv Polytechnic National University, Lviv, Ukraine}

Received 20 February 2019; accepted 8 July 2019

* Corresponding author. E-mail: mykola.sysyn@tu-dresden.de

Mykola SYSYN (ORCID ID 0000-0001-6893-00181)

Vitalii KOVALCHUK (ORCID ID 0000-0003-4350-17562)

Olga NABOCHENKO (ORCID ID 0000-0001-6048-25563)

Yuri KOVALCHUK (ORCID ID 0000-0002-1151-57854)

Oleg VOZNYAK (ORCID ID 0000-0002-7163-90265) 
distribution are carried out with the developed microcontroller system of measurements and developed load cells. The system allows performing multi-point measurements of stress in combination with measurements of acceleration and photogrammetry. The results of measurements showed a significant effect of the ballast layer consolidation on the distribution of stresses under the sleeper. The performed research opens up opportunities for practical improvement of the existing types of track structures and the technology of the ballast layer tamping in terms to provide the optimal conditions for the ballast layer operation.

Keywords: ballast consolidation, load cell, pressure distribution, pressure measurement, railway ballast, tamping.

\section{Introduction}

The economic efficiency and competitiveness of the railway transport directly depend on the cost of its infrastructure. Unlike other types of transport, railway transport has a high cost of construction and maintenance of the infrastructure, which includes the superstructure of the track, engineering facilities, power supply and signalling devices. The investment costs into the superstructure of the track and turnouts are only $5 \%-7 \%$ of the total cost of the railway infrastructure (Fendrich \& Fengler, 2013). In contrast with that, the share of the cost for maintaining the superstructure of the track is almost $50 \%$ of the total costs for maintaining the railway infrastructure. The reason for this is a short lifetime of the elements of the track, and the necessity for frequent and expensive maintenance works for the track. The rapid deterioration of the track requires, in its turn, high costs for its inspection.

Works on the maintenance of the track require breaks in train operation, which lead to significant loss during heavy traffic. The ballast layer of the track, which influences the occurrence of irregularities in the geometry of the track, is an element that requires frequent corrective interventions. The average inter-repair period of the tracklayer tamping is 40-70 million tons (Lichtberger, 2005) with the total lifecycle of other elements of the track 500-1000 million tons. The short lifecycle of the ballast layer is due to its mechanical properties and its technical function in the system of the track superstructure.

One of the main tasks of the superstructure of the track is the possibility to get horizontal, vertical and longitudinal loads from the rolling stock and transfer them from the rails through the elements of fastenings, sleepers and the ballast on the subgrade. The stress in the elements of the track gradually decreases from the point of contact of the wheel and the rail to the subgrade due to the distribution of loads on a larger area. Figure 1 shows a schematic explanation of the stress
Experimental Study of Railway Trackbed Pressure Distribution Under Dynamic Loading 


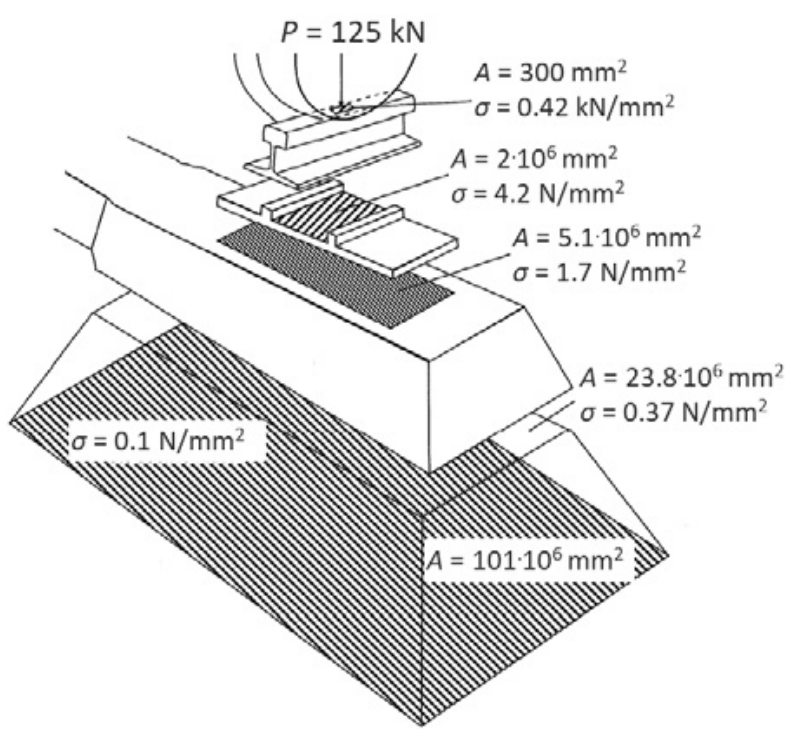

Figure 1. Schematic explanation of the stress distribution from the wheel to the surface of the subgrade (modified after Führer (1978))

distribution from the point of contact of the wheel and the rail to the surface of the subgrade.

At the same time, stress distribution by the ballast layer under the sleeper is not homogeneous and depends on a number of factors. The main of them is the uneven distribution of the ballast layer properties due to the different level of consolidation of the ballast layer. During ballast tamping by tamping machines, zones of consolidation are being created under the rails. The zones, during the cyclical loading by the trains, are being loosened because of the movement and breakage ballast particles. The importance of the ballast layer consolidation in the process of railway operation is shown in a series of practical studies and scientific works. In studies Esveld (2001) and Lichtberger (2005), it has been shown that the ballast layer consolidation by dynamic stabilisation prevents unevenness occurrence and extend the repair interval more than twice. The determination of the ballast layer consolidation on the ground of acceleration measurements was proposed by Liu, Huang, \& Qiu (2018), Sysyn, Kovalchuk, Gerber, Nabochenko, \& Parneta (2019) and Sysyn, Nabochenko, Kovalchuk, \& Gerber (2019). Beben (2017) and Kovalchuk, V., Kovalchuk, Y., Sysyn, Stankevych, \& Petrenko (2018) investigated the effect of the consolidation quality of ballast material on the bearing capacity of the engineering structures of the railway track. Gerber \& Fengler (2010) and Sysyn, Gerber, Kovalchuk, 
\& Nabochenko (2018) proposed the estimation of the unevenness development of the track based on phenomenological models of uneven subsidence of the ballast layer concerning the initial consolidation of the ballast layer. Kumara \& Hayano (2016) investigated the movements of the ballast layer particles in ballast layer after tamping of clean and contaminated ballasts. Computer simulation of inhomogeneous ballast subsidence on the track and common crossings, which takes into account ballast consolidation, were presented by Nabochenko, Sysyn, \& Kovalchuk (2019) and Sysyn, Gerber, Gruen, Nabochenko, \& Kovalchuk (2019). Fischer (2017), Juhász \& Fischer (2019) and Ramūnas, Vaitkus, Laurinavičius, Čygas, \& Šiukščius (2017) present the study of the ballast layer particles breakage during their lifecycle, depending on their mechanical properties. Full-scale laboratory investigation of railway ballast behaviour under operational loading and tamping maintenance is presented by Aursudkij (2007) and Čebašek, Esen, Woodward, Laghrouche, \& Connolly (2018). In-situ monitoring and theoretical modelling of accelerated inhomogeneous ballast settlements in transition zones from ballasted to ballastless track are shown in studies of Ižvolt, Šestáková, \& Šmalo (2016; 2017). Ižvolt, Harusinec, \& Šmalo (2018) studied optimisation of ballasted track transition zones with under sleeper pads. Plasek \& Hruzikova (2017), Plasek, Hruzikova, Svoboda, \& Bilek (2014) and Plasek, Hruzikova, Svoboda, \& Vendel (2015) presented studying the influence of under sleeper pads on the inhomogeneous ballast settlements and track geometry deterioration in turnouts and track. Theoretical investigation of pressure distribution properties of railway ballast is presented in the paper of Kumar, Suhr, Marschnig, Dietmaier, Marte, \& Six (2019). Discrete element modelling was used to study the influence of elastic layers under the sleeper and the ballast layer on the particle movement, contact forces and breakage. The study confirms the positive influence of under sleeper pads on the particle breakage as well as the influence of under ballast mat on higher particle movement throughout the trackbed. Gerber, Sysyn, Zarour, \& Nabochenko (2019) demonstrate an experimental investigation of ballast layer carrying capacity under the cyclic loading. The scaled model of a structural layer of ballast material with side support was used for the investigation. The experiment tests show that the ballast stiffness as well as its strength are interrelated and are influenced with the support stress.

The experimental measurements of the ballast pressure between the sleeper and the ballast and under the trackbed with hydraulic load cells were presented by Liu, Lei, Rose, \& Purcell (2017) and Watts, Rose, \& Russell (2018). Aikawa (2015) proposes the dynamic pressure measurements of the railway ballast with a special sensing sleeper and a
Experimental Study of Railway Trackbed Pressure Distribution Under Dynamic Loading 
three-dimensional sensing stone. The foot of sleeper was equipped with 75 impact-loading sensors.

The problem of stress measurements in the ballast layer, which is a granular material, consists of significant accidental stress dispersion due to the random location of ballast grains. Two principal methods are used to compensate the problem, i.e. the increase of the measurement area compared to the size of the grains (Liu, Lei, Rose, \& Purcell, 2017), or multi-point measurements with the following statistical analysis. The advantage of the second method is the higher resolution of measurements of the spatial distribution of stresses. The lack of the method is a high cost due to the need for a large number of load cells and measuring channels. In this paper, the development of measuring equipment is proposed based on standard cost-effective sensor modules and microcontroller modules. Such a concept provides simultaneously effective and qualitative technical solutions.

In this paper, the task of the experimental study of stress distribution at the ballast layer during cyclic and vibration loads on the sleeper is presented. For this purpose, the equipment is developed for simultaneous measurement of stresses and accelerations in the ballast layer for laboratory and field measurements. In the laboratory experiment, the ballast layer model investigates the effect of ballast consolidation on the distribution of stresses along with the sleeper.

\section{Measurement method and laboratory setup}

The determination of the stress state of the ballast was carried out with the help of the developed integrated mobile measurement system. The main components of the system are the developed stress measurement sensor and the measured data processing device. The system is designed to provide autonomous, multi-point monitoring of dynamic stresses and displacements in the devices of the track infrastructure. The block diagram of the mobile system of ballast stress measurement is shown in Figure 2.

The device consists of a microcontroller ESP-32, which manages two 24-bit analogue-to-digital converters ADS 1256. Besides, the microcontroller is to receive and digitise analogue signals from stress sensors, pre-process, estimate and store information with the output of information on the screen of the display about the progress of the work. Analogue information from 16 channels of stress signals is digitised with the frequency of $300 \mathrm{~Hz}$. Before starting to conduct stress measurements at the ballast layer, the microcontroller is synchronised with real-time through the timeserver of the global Internet network. 


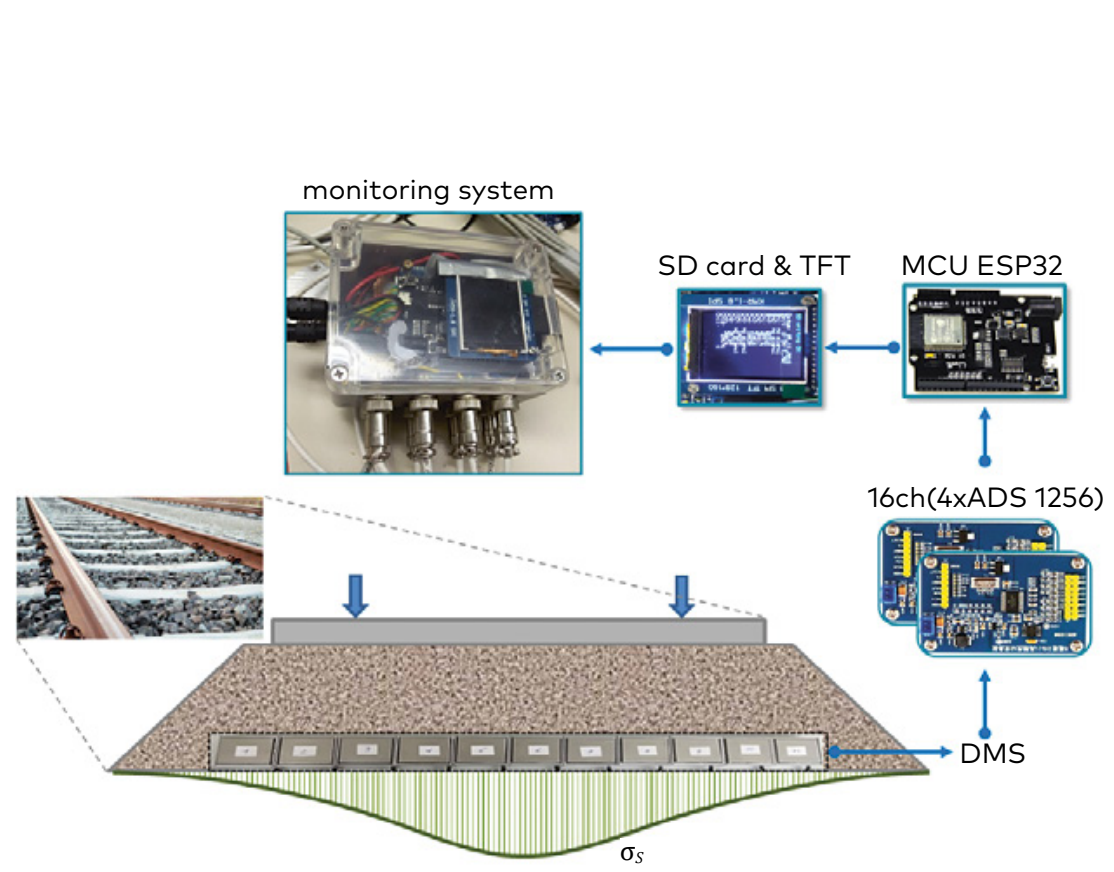

Mykola Sysyn,

Experimental Study of Railway Trackbed Pressure Distribution Under Dynamic Loading

Figure 2. Structural scheme of the mobile system for conducting measurements of the stressed state of the ballast layer of the railway track

After synchronising a real-time microcontroller using the developed DMS-Spannung software, the programmed ESP-32 microcontroller launches ADS 1256 analogue-to-digital converter. After the hydro pulse loading device ZWICK HB 160 loads ballast, the load cells send a signal to the measuring equipment of the system where the signal collection, processing and storing on the SD card of the device takes place.

Load cells are metal boxes of $4.0 \times 4.0 \times 2.0 \mathrm{~cm}$ in size (Figure 2), inside which two consecutively connected half-bridge load cells modules with strain gauges. For measurements balancing, a full bridge circuit connects the sensors. The maximum nominal load on the sensor is $50 \mathrm{~kg}$ that allows performing stress measurements up to $0.4 \mathrm{MPa}$ without the necessity to compensate for nonlinear properties. The dimensions of the active surface of the sensor are selected regarding the need to measure the pressure of the granular ballast material. In experimental laboratory studies, the model ballast of fraction $8-16 \mathrm{~mm}$ is used that is entirely sufficient for stable measurement of pressure by developed load cells (Figure 3).

The stand for the research of the stressed state of the ballast is the box of the size $1.0 \times 0.17 \times 0.33 \mathrm{~m}$ filled with crushed stone (Figure 4 ). The sidewalls of the box are thick-walled glass plates to monitor the movement of ballast particles and perform photogrammetric measurements. Crushed stone is the granite fraction $8 / 16$, which fills the entire perimeter of the 


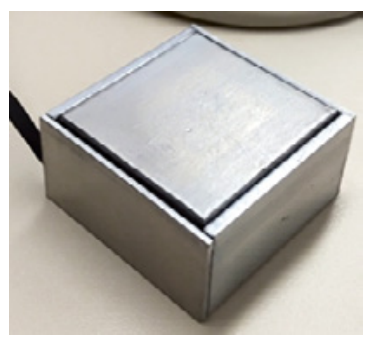

a) load cell

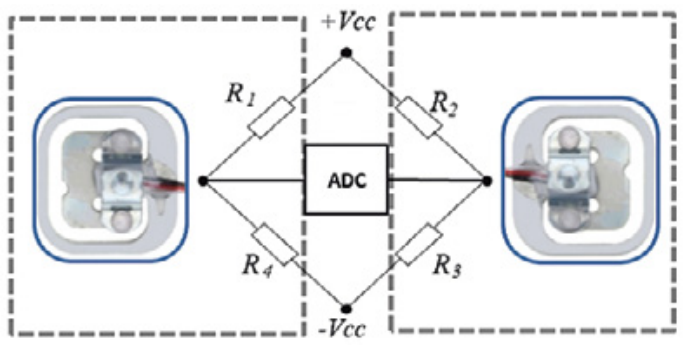

b) a full-bridge circuit connection of two standard load cells

Figure 3. Load cells structure for ballast pressure measurement

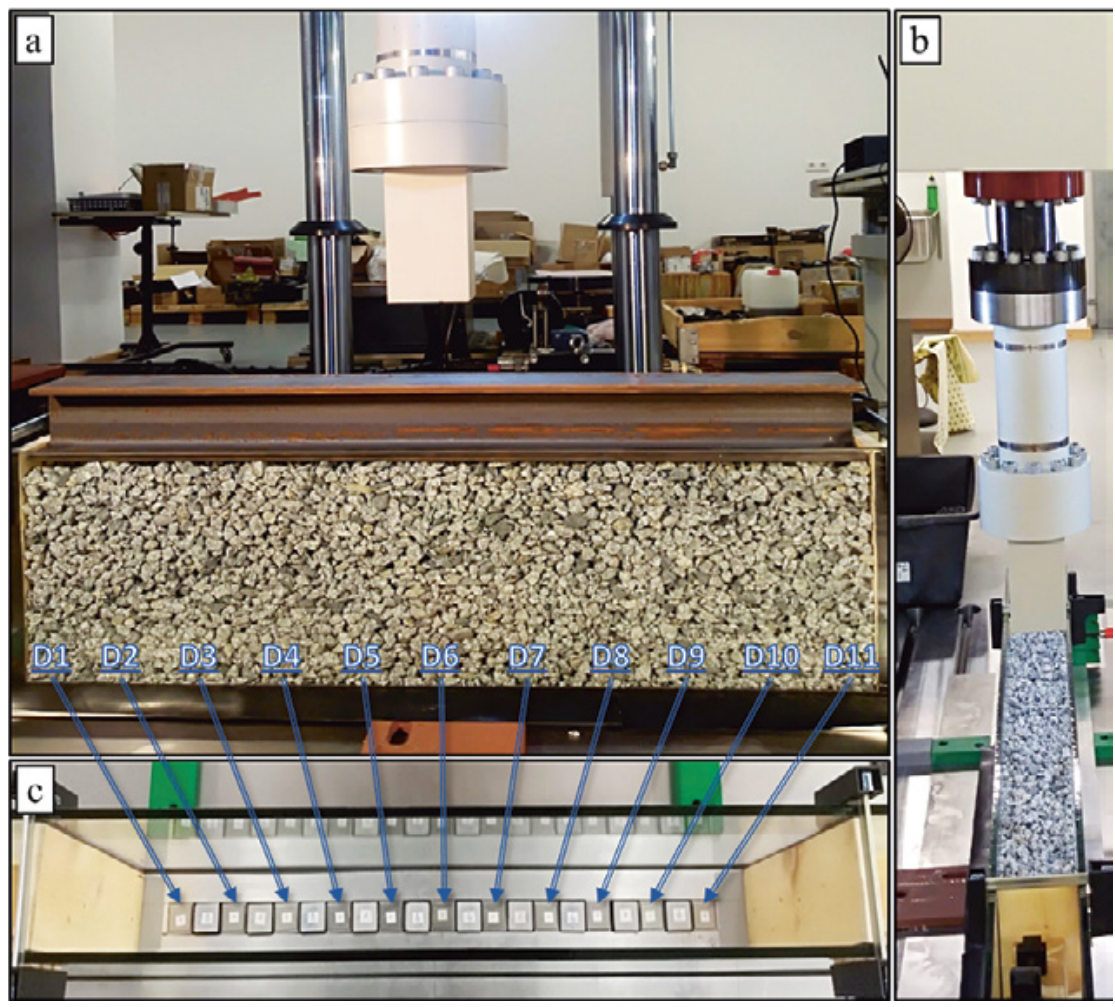

Note: a) the front view of the ballast in the box with glass walls; b) the side view; c) the position of loading sensors under the ballast.

Figure 4. Experimental tests of the stressed ballast state of the railway track without additional ballast consolidation 
box to the depth of $0.27 \mathrm{~m}$ without consolidation. The selection of the crushed stone in the model scale takes into account the possibility of the pressure measurement using the load cells with active area $37 \times 37 \mathrm{~mm}$. The end walls are capable of longitudinal displacement when the ballast pressure reaches friction resistance. The bottom of the box consists of u-shaped profiles, where signal cables and power supply to the sensors are placed. The total number of stress sensors is $11 \mathrm{pcs}$.

\section{Experimental measurements of the stressed state under the ballast layer}

The laboratory studies of stresses under the ballast were performed by a sequence of load cycles with ZWICK HB 160 hydro pulse device. The ballast load was transmitted through a metal I-beam with the length $1 \mathrm{~m}$. The geometric dimensions of the beam are chosen so that while transferring loads from the hydro pulse, the entire perimeter of the ballast prism base is covered. The bending stiffness of the beam with the second moment of area $534 \mathrm{sm}^{4}$ is much higher than the area of the correspondent to B70 model scaled sleeper (185-290 sm ${ }^{4}$ ) and therefore it is assumed as a rigid stamp. The change of the shape of the ballast prism and types of loads, as well as the results of sleeper subsidence in eight different experimental load cycles, are shown in Figure 5. In each cycle of the experiment, the controlled static and dynamic load with a Zwick HB160 loading machine is applied to the stamp and simultaneously, the dynamic subsidence of a sleeper is measured. In the initial cycles, the load corresponds to the cyclic load from the rolling stock with pre-loading and the dynamic component. For each next cycle, the load rises. The end cycle corresponds to vibration loading with a frequency close to the own frequency of fluctuations of the rail-sleeper grid. Such a load is expected to lead to the fastest accumulation of irreversible deformations in the ballast layer.

At the beginning of the experiment, in cycle No. 1, the static load of $0.5 \mathrm{kN}$ and a duration of 30 seconds were applied. The residual subsidence of the ballast was not observed. During cycle No. 2, a constant load of $5 \mathrm{kN}$ and further dynamic harmonic load at the frequency of $10 \mathrm{~Hz}$ and the amplitude of $1 \mathrm{kN}$ were applied. At the given load, the ballast layer subsidence was $0.8 \mathrm{~mm}$. Both cycle No. 1 and cycle No. 2 are carried out for the limited slopes with sidewalls. The sidewalls are shifted to $50 \mathrm{~mm}$ in each side of the sleeper for the cycle No. 2. The further cycles are carried out with free slopes. 

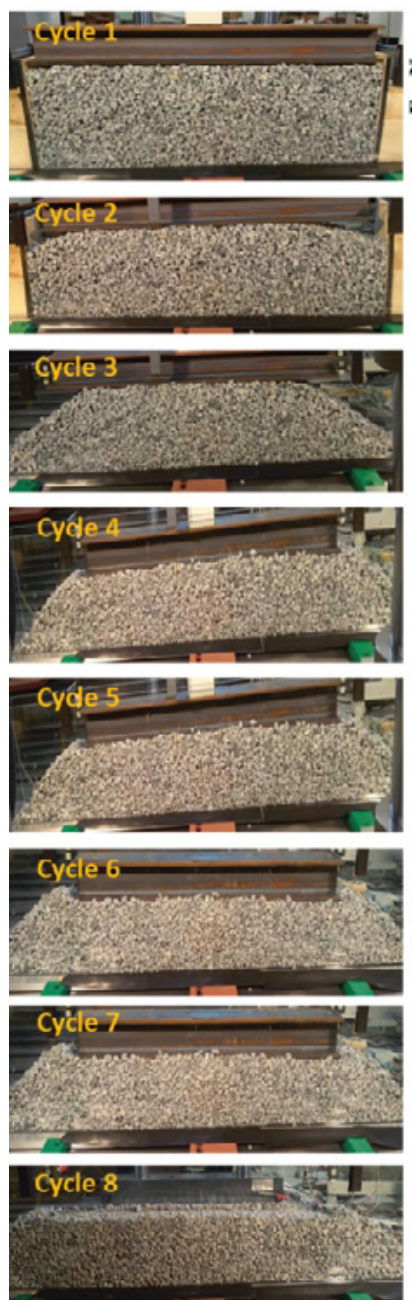

the process of change of the ballast prism shape after loads
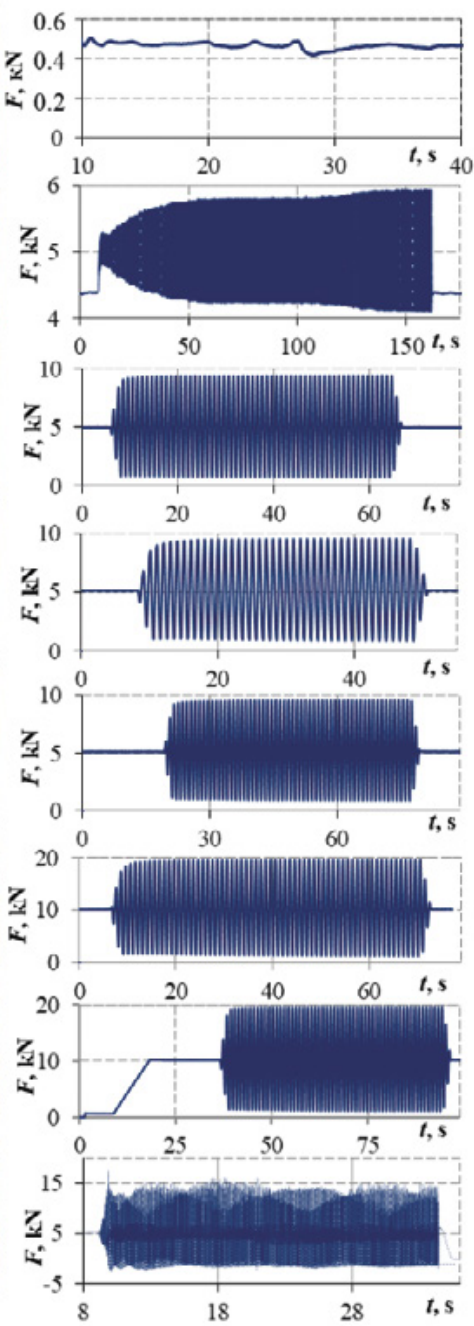

the type of applied load with the magnitude of force and duration of action
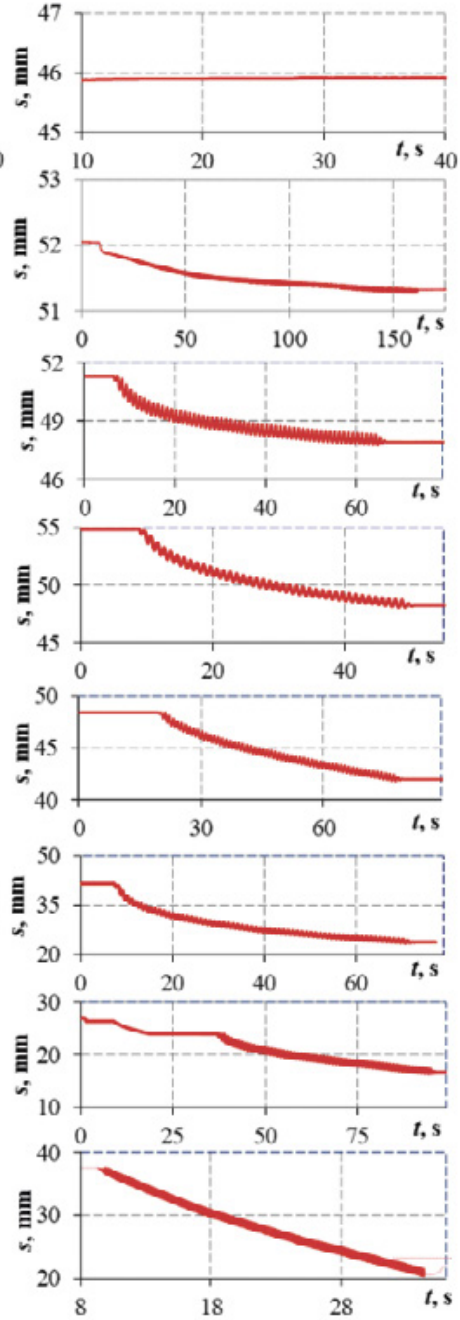

the ballast subsidence after each load cycle

Figure 5. The process of studying the stressed state of the ballast under laboratory conditions

A smooth change in the load from $0 \mathrm{kN}$ to $5 \mathrm{kN}$ and further dynamic harmonic load at the frequency of $1 \mathrm{~Hz}$ in the range from $-4.5 \mathrm{kN}$ to $+4.5 \mathrm{kN}$ were applied in load cycles No. 3, No. 4 and No. 5. The total subsidence of the ballast in experiment No. 3 was $3.5 \mathrm{~mm}$ for 35 load 
cycles; in experiment No. 4 it was $7 \mathrm{~mm}$ for 25 load cycles, and in experiment No. 5 it was $6 \mathrm{~mm}$ for 35 load cycles.

During experimental load cycle No. 6, the static load was $10 \mathrm{kN}$, and further dynamic harmonic load at the frequency of $1 \mathrm{~Hz}$ in the range from $-9.5 \mathrm{kN}$ to $+9.5 \mathrm{kN}$ was applied. The ballast subsidence was $9.5 \mathrm{~mm}$ per 100 load cycles. During performing cycle No. 7, the smooth change in load from $0 \mathrm{kN}$ to $10 \mathrm{kN}$ was used. After, the further dynamic harmonic load at the frequency of $1 \mathrm{~Hz}$ in the range from $-9.5 \mathrm{kN}$ to $+9.5 \mathrm{kN}$ was applied. The total subsidence of the ballast in experiment number 7 was $14 \mathrm{~mm}$ per 100 load cycles.

In the cycle No. 8, the static load was $5 \mathrm{kN}$, and the total dynamic load on the stamp was $19 \mathrm{kN}$ at the frequency of $40 \mathrm{~Hz}$. During the experiment, there was a complete discharge of the ballast. The ballast subsidence was $19 \mathrm{~mm}$ per 1200 cycles of harmonic load for 30 seconds.

During each load cycle, stress measurements were carried out at the ballast layer with the help of the developed integrated mobile system of stress measurement. In addition to stresses, simultaneous measurements of the velocity of the passage of the longitudinal and transverse pulsed waves were carried out using other developed systems.

\section{Analysis of the influence of dynamic loading on the trackbed pressure distribution}

All the load cells were calibrated before measurements. During measurements execution, significant residual stresses in the load cells under the centre of the sleeper were observed. In other words, after loading removal between cycles, the load cells recorded specific values of stresses. The task of residual stresses investigation is considered in a separate study. In this study, only dynamic values of stresses are used, that is, at the beginning of each cycle, before new loading, all the stresses are shifted to zero.

The distribution of stresses under the ballast along the axis of a sleeper at different load cycles is shown in Figure 6. During the first four cycles of loading, the stress along with the sleeper was distributed almost evenly to $30 \mathrm{kPa}$ for the third and fourth cycles. Starting from the fifth cycle, when limits of ballast movement at the ends of the sleeper are removed, the stress on 2-3 side load cells at each edge of the sleeper is smoothly reduced to the level of 1-2 cycles. The stress in the ballast under the middle part of the sleeper increases slightly. The relative 
homogenous pressure distribution along with the sleeper over the first 4 cycles confirms the assumption of the beam as the rigid stamp.

The external load rises twice without changing the frequency of cycles in No. 6 and No. 7 cycles. At the same time, there is a significant increase in stresses under the middle part of the sleeper up to $70 \mathrm{kPa}$. Under the ends of the sleeper, the stress remains approximately at the level of first cycles, although the sleeper visually has the full support of the ballast.

From the second to the eighth cycle, the cyclic load, simulating the passage of the axles of the rolling stock, is applied on the sleeper. In the last cycle No. 8 vibration loading of $40 \mathrm{~Hz}$ is applied on the sleeper, which approximately corresponds to the frequency of the own vibration of the track. Such a load is applied by tamping machines and a dynamic stabiliser (Lichtberger, 2005) for the ballast layer losing. After 1000 cycles of vibration load and sleeper subsidence for $18 \mathrm{~mm}$, the stress under the central load cells increases up to $15 \%$, while the stresses at the ends of the sleeper increase 2-3 times. Thus, the ballast layer is homogenised. Whereas before vibration load application, the unevenness of stresses at the edges of the sleeper relatively to the stresses in the middle is $90 \%-95 \%$, then, after homogenization, the unevenness of stresses is $60 \%-70 \%$. It is noted that the growth of the amplitude of dynamic stresses in the last cycle occurs without changing the amplitude of the external load. This phenomenon is explained by the appearance of the dynamic effects of the ballast vibrations with a frequency close to the vibrations of the system.

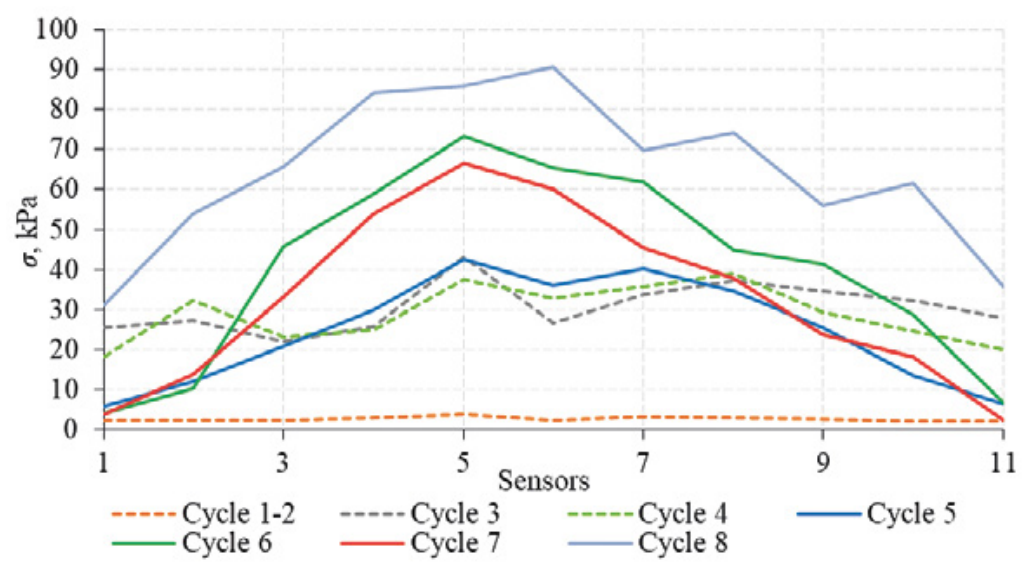

Figure 6. Distribution of maximum stresses under the ballast depending on the program of experimental research 
The load from the sleeper is distributed in a larger area, as shown in Figure 1. Therefore, the stress from the ballast surface under the sleeper to the ballast layer is reduced; that is, it is possible to apply the analogy to the load distribution angle. Conforming to the method described by Steiner, Kuttelwascher, \& Prager (2014) and Berghold (2016), the load distribution angle under the action of dynamic load is calculated depending on the distribution of stresses under the sleeper. At the maximum values of stresses under the ballast, the accumulated amount of stresses is calculated for each of the measuring sensors. The maximum last value of the sum is assumed to equal to $100 \%$, and then at each of the measuring sensors, the percentage of the incoming stress is determined concerning the maximum amount. Beyond the limits of stress distribution, a window of $90 \%$ width of a quantile of $5 \%$ to $95 \%$ is taken. Within 5\% up to the sleeper edge from one side, the extra distance of the distribution area is determined. As a result, the angle of load distribution is taking into account the height of the ballast layer and the horizontal distance from the edge of the sleeper to the boundary of $5 \%$ of stress distribution.

Figure 7 shows the load distribution angle obtained using the values of maximum stresses in the last cycle of experimental dynamic studies.
Mykola Sysyn, Vitalii Kovalchuk, Olga Nabochenko, Yuri Kovalchuk, Oleg Voznyak

Experimental Study of Railway Trackbed Pressure Distribution Under Dynamic Loading

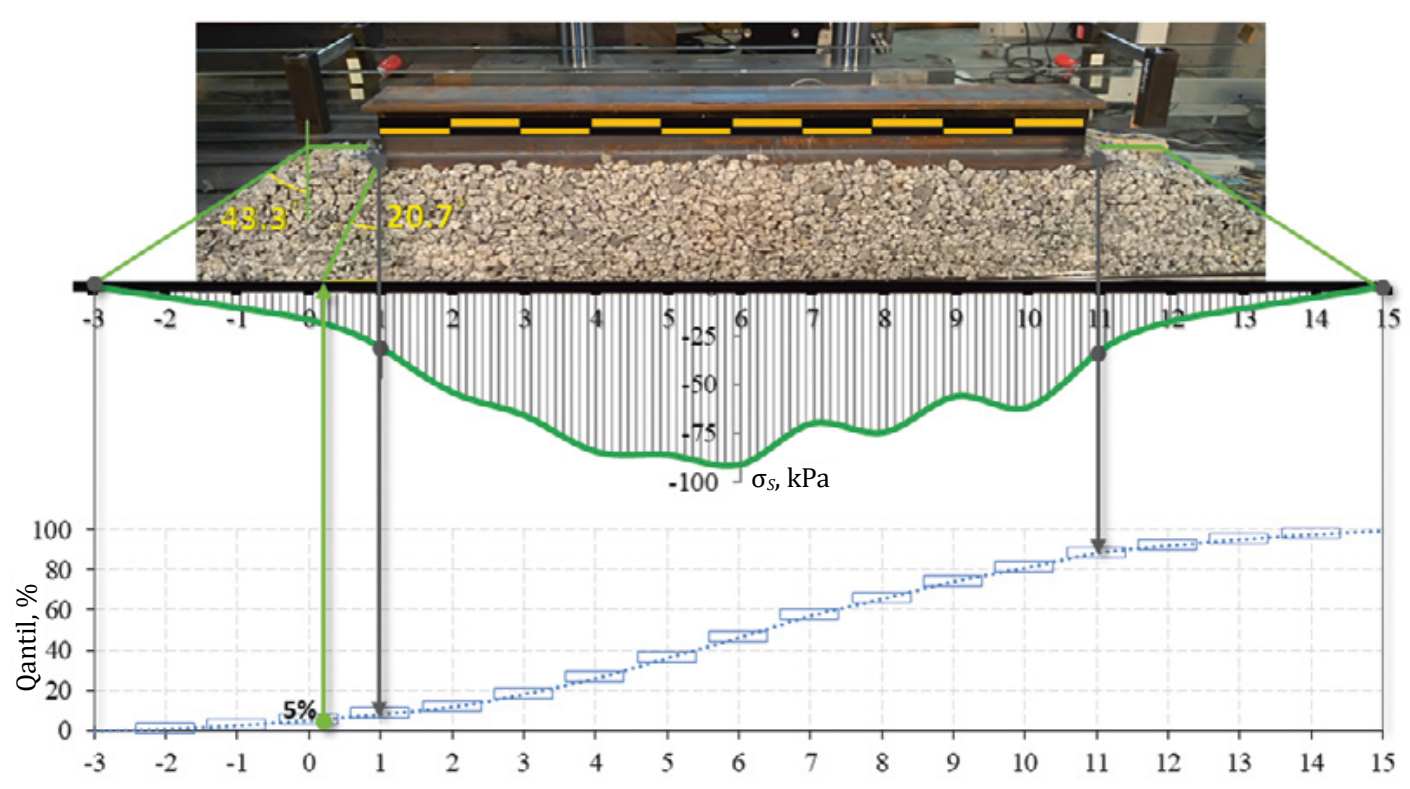

Figure 7. The angle of load distribution after the action of vibration loading on the ballast in cycle No. 8 
Table 1. The comparison of pressure distribution under the sleeper and the ballast for central sensor No. 6

\begin{tabular}{|c|c|c|c|c|c|c|c|c|}
\hline Parameter & Cycle 1 & Cycle 2 & Cycle 3 & Cycle 4 & Cycle 5 & Cycle 6 & Cycle 7 & Cycle 8 \\
\hline $\begin{array}{l}\text { Pressure } \\
\text { under the sleeper, } \mathrm{kPa}\end{array}$ & - & 8.85 & 43.30 & 42.00 & 42.70 & 90.15 & 91.55 & 88.50 \\
\hline $\begin{array}{l}\text { Pressure } \\
\text { under the ballast, } \mathrm{kPa}\end{array}$ & - & 4.30 & 37.80 & 43.10 & 43.20 & 65.60 & 73.50 & 91.20 \\
\hline Ballast height, $\mathrm{mm}$ & 270 & 269 & 265 & 258 & 252 & 238 & 231 & 212 \\
\hline $\begin{array}{l}\text { Pressure distribution } \\
\text { angle } \alpha,^{\circ}\end{array}$ & - & - & - & - & 8.10 & 10.30 & 12.50 & 20.70 \\
\hline
\end{tabular}

In this case, it is 20.7 degrees that correspond to the result obtained by Steiner, Kuttelwascher, \& Prager (2014), where the value of this angle is 19.0-24.5 degrees for a new granite railway ballast of the original size. Moreover, the angle of the natural slope is 43.3 degrees.

The described technique is largely subjective due to insufficiently justified choice of the width of the load distribution window. In addition, the parameter of consolidation quality obtained in this way depends not only on the properties of the ballast material but also on many factors, such as under-rail padding, the form of a sleeper.

Nevertheless, this parameter is a technically understandable criterion for assessing the quality of the ballast layer stabilisation. The calculation of the stress distribution angle for all other cycles, as well as the comparison of maximum stresses under the sleeper and the ballast, is given in Table 1. The pressure distribution angles for No. 1, No. 2, No. 3 and to No. 4 cycles are not calculated due to the absence of a free slope of the shoulder of the ballast prism. From the calculation, it is evident that after the homogenising action of the vibration loading, the pressure distribution angle is almost doubled.

\section{Discussion}

The development and application of the method for determining the stress state of the ballast layer showed a significant change of the stresses in the process of its deformation under the sleeper, depending on the program of experimental research. The effect of uneven stresses is related to uneven ballast consolidation under the sleeper. The unevenness of stresses under the influence of cyclic loads 
of $1 \mathrm{~Hz}$, corresponding to the action of the axles of the rolling stock, has 3-5 times higher value under the middle part of the sleeper than at its edges, that is from $10 \mathrm{kPa}$ to $40 \mathrm{kPa}$. The double increase of the external load with constant frequency did not lead to a noticeable increase in the uniformity of stress distribution. The action of the vibration loading of $40 \mathrm{~Hz}$ causes an intensive ballast movement under the sleeper, which leads to homogenization of stress distribution. After the action of the vibration loading and the sleeper subsidence for $18 \mathrm{~mm}$, the stresses under the middle part of the sleeper increase insignificantly, whereas the stresses at the edges of the sleeper increase 2-3 times. Before the vibration loading, the unevenness of stresses at the edges of the sleeper relatively to the stresses in the middle part of the sleeper is $90 \%-95 \%$. Then, after homogenization, the unevenness of stresses is $60 \%-70 \%$.

The analysis of the load distribution angle from the sleeper to the ballast prism base also shows a significant increase in the distribution properties of the ballast layer after the vibration loading. The maximum value of the given angle is 20.7 degrees after the action of vibration, which is twice as large as in the state before consolidation. Despite this, and after the maximum achieved consolidation, the heterogeneity of load distribution remains significant. Theoretically, the load distribution angle could be increased to the angle of internal friction, which is about 43.3 degrees in our case. Thus, in the distribution properties of the ballast layer, there is a significant reserve that can be achieved by optimising the consolidation technology of the ballast layer and the construction of the superstructure.

However, it should be noted that the stress distribution in the real track is influenced by the bending stiffness of the sleeper as well as the stiffness of subsoil, here represented by the stiffness of the box bottom and the stress sensor cells. The test results were received only for one experiment. The results are valid for the presented test arrangement and conditions bending stiffness of load beam, the fraction of crushed stone, stiffness of the support in the box and taking into account the notes a promising purpose for future research.

\section{Conclusions}

The conclusions from the experimental tests of the ballast layer are as follows:

1. The cyclic loading on the model sleeper causes a concentration of the maximal pressure under the middle part of the sleeper, whereas the vibration loading causes homogenization of the pressure distribution. 
2. Before the vibration loading, the unevenness of stresses at the edges of the sleeper relatively to the stresses in the middle part of the sleeper is $90 \%-95 \%$.

3. After the ballast layer homogenization with the dynamic loading, the unevenness of stresses is $60 \%-70 \%$.

4. The vibration loading homogenises the pressure distribution in the ballast layer under the sleeper that results in the almost doubled increase of pressure distribution angle.

\section{REFERENCES}

Aikawa, A. (2015). Dynamic characterisation of a ballast layer subject to traffic impact loads using three-dimensional sensing stones and a special sensing sleeper. Construction and Building Materials, 92, 23-30. https://doi.org/10.1016/j.conbuildmat.2014.06.005

Aursudkij, B. (2007). A laboratory study of railway ballast behaviour under traffic loading and tamping maintenance (Doctoral dissertation, University of Nottingham).

Beben, D. (2017). The Role of Backfill Quality on Corrugated Steel Plate Culvert Behaviour. Baltic Journal of Road \& Bridge Engineering (Baltic Journal of Road \& Bridge Engineering), 12(1), 1-11. https://doi.org/10.3846/bjrbe.2017.01

Berghold, A. (2016). Wirkungsweise von unterschiedlichen Gleisschotterarten mit und ohne Schwellenbesohlungen. ZEVrail, 2016(A20420E), 45-52. (in German)

Čebašek, T. M., Esen, A. F., Woodward, P. K., Laghrouche, O., \& Connolly, D. P. (2018). Full scale laboratory testing of ballast and concrete slab tracks under phased cyclic loading. Transportation Geotechnics, 17, 33-40. https://doi.org/10.1016/j.trgeo.2018.08.003

Esveld, C. (2001). Modern railway track (Vol. 385). Zaltbommel: MRT-productions.

Fendrich, L., \& Fengler, W. (Eds.). (2014). Handbuch Eisenbahninfrastruktur. Springer-Verlag. https://doi.org/10.1007/978-3-642-30021-9 (in German)

Fischer, S. (2017). Breakage test of railway ballast materials with new laboratory method. Periodica Polytechnica Civil Engineering, 61(4), 794-802. https://doi.org/10.3311/PPci.8549

Führer, G. (1978). Oberbauberechnung. VEB, Verlag für Verkehrswesen, Berlin. 151 pp. (in German).

Gerber, U., \& Fengler, W. (2010). Setzungsverhalten des Schotters. ETR. Eisenbahntechnische Rundschau, 59(4), 170-175. (in German)

Gerber, U., Sysyn, M., Zarour, J., \& Nabochenko, O. (2019). Stiffness and strength of structural layers from cohesionless material. Archives of Transport, 49(1), pp. 59-68. https://doi.org/10.5604/01.3001.0013.2776

Ižvolt, L., Harusinec, J., \& Šmalo, M. (2018). Optimisation of transition areas between ballastless track and ballasted track in the area of the tunnel 
turecky vrch. Communications-Scientific letters of the University of Zilina, 20(3), 67-76.

Ižvolt, L., Šestáková, J., \& Šmalo, M. (2016). Analysis of results of monitoring and prediction of quality development of ballasted and ballastless track superstructure and its transition areas. Communications-Scientific letters of the University of Zilina, 18(4), 19-29.

Ižvolt, L., Šestáková, J., \& Šmalo, M. (2017, September). Tendencies in the development of operational quality of ballasted and ballastless track superstructure and transition areas. In IOP Conference Series: Materials Science and Engineering (Vol. 236, No. 1, p. 012038). IOP Publishing. https://doi.org/10.1088/1757-899x/236/1/012038

Juhász, E., \& Fischer, S. (2019). Investigation of railroad ballast particle breakage. Pollack Periodica, 14(2), 3-14. https://doi.org/10.1556/606.2019.14.2.1

Kovalchuk, V. V., Kovalchuk, Y. Y., Sysyn, M. P., Stankevych, V. Z., \& Petrenko, O. V. (2018). Estimation of carrying capacity of metallic corrugated structures of the type multiplate mp 150 during interaction with backfill soil. https://doi.org/10.15587/1729-4061.2018.123002

Kumar, N., Suhr, B., Marschnig, S., Dietmaier, P., Marte, C., \& Six, K. (2019). Micro-mechanical investigation of railway ballast behavior under cyclic loading in a box test using DEM: effects of elastic layers and ballast types. Granular Matter, 21(4), 106. https://doi.org/10.1007/s10035-019-0956-9

Kumara, J. J., \& Hayano, K. (2016). Deformation characteristics of fresh and fouled ballasts subjected to tamping maintenance. Soils and foundations, 56(4), 652-663. https://doi.org/10.1016/j.sandf.2016.07.006

Lichtberger, B. (2005). Track Compendium: Formation, Permanent Way, Maintenance. Economics, 1.

Liu, Q., Lei, X., Rose, J. G., \& Purcell, M. L. (2017, April). Pressure Measurements at the Tie-Ballast Interface in Railroad Tracks Using Granular Material Pressure Cells. In 2017 Joint Rail Conference. American Society of Mechanical Engineers Digital Collection. https://doi.org/10.1115/JRC2017-2219

Liu, S., Huang, H., \& Qiu, T. (2018). Evaluating Ballast Stabilization during Initial Compaction Phase. In Railroad Ballast Testing and Properties. ASTM International. https://doi.org/10.1520/STP160520170032

Nabochenko, O., Sysyn, M., \& Kovalchuk, V. (2019). Studying the railroad track geometry deterioration as a result of an uneven subsidence of the ballast layer. Eastern-European Journal of Enterprise Technologies, 97(1), 50-59. https://doi.org/10.15587/1729-4061.2019.154864

Plasek, O., \& Hruzikova, M. (2017, September). Under sleeper pads in switches \& crossings. In IOP Conference Series: Materials Science and Engineering (Vol. 236, No. 1, p. 012045). IOP Publishing.

Plasek, O., Hruzikova, M., Svoboda, R., \& Bilek, J. (2014). Under sleeper pads in railway track. Communications - Scientific Letters of the University of Zilina, 16(4), pp. 27-34.

Plasek, O., Hruzikova, M., Svoboda, R., \& Vendel, J. (2015). Influence of under sleeper pads on track quality. AKUSTIKA, 23, 28-33.
Experimental Study of Railway Trackbed Pressure Distribution Under Dynamic Loading 
Ramūnas, V., Vaitkus, A., Laurinavičius, A., Čygas, D., \& Šiukščius, A. (2017). Prediction of lifespan of railway ballast aggregate according to mechanical properties of it. The Baltic Journal of Road and Bridge Engineering, 12(3), 203-209. https://doi.org/10.3846/bjrbe.2017.25

Steiner, E., Kuttelwascher, C., \& Prager, G. (2014). Lastabtragung im Schotterbett - Änderungseffekte durch Konsolidierung und Bahnbetrieb. ETR - Eisenbahntechnische Rundschau, 12, pp.72-76. (in German)

Sysyn, M., Gerber, U., Gruen, D., Nabochenko, O., \& Kovalchuk, V. (2019). Modelling and vehicle based measurements of ballast settlements under the common crossing. Eur Transp Int J Transp Econ Eng Law, 71, 1-25.

Sysyn, M., Gerber, U., Kovalchuk, V., \& Nabochenko, O. (2018). The complex phenomenological model for prediction of inhomogeneous deformations of railway ballast layer after tamping works. Archives of Transport, 47. https://doi.org/10.5604\%2F01.3001.0012.6512

Sysyn, M., Kovalchuk, V., Gerber, U., Nabochenko, O., \& Parneta, B. (2019). Laboratory Evaluation of Railway Ballast Consolidation by the Non-Destructive Testing. Communications-Scientific letters of the University of Zilina, 21(2), 81-88.

Sysyn, M., Nabochenko, O., Kovalchuk, V., \& Gerber, U. (2019). Evaluation of railway ballast layer consolidation after maintenance works.

Watts, T. J., Rose, J. G., \& Russell, E. J. (2018, April). Relationships Between Wheel/Rail Surface Impact Loadings and Correspondingly Transmitted Tie/ Ballast Impact Pressures for Revenue Train Operations. In 2018 Joint Rail Conference. American Society of Mechanical Engineers Digital Collection. https://doi.org/10.1115/JRC2018-6184 